\title{
LEVERAGE AND HOUSE-PRICE DYNAMICS IN U.S. CITIES
}

Owen Lamont

Jeremy C. Stein

Working Paper 5961

\author{
NATIONAL BUREAU OF ECONOMIC RESEARCH \\ 1050 Massachusetts Avenue \\ Cambridge, MA 02138 \\ March 1997
}

This research is supported by: the FMC Faculty Research Fund at the Graduate School of Business, University of Chicago (Lamont); the National Science Foundation (Stein); and the Finance Research Center at MIT (Stein). We are grateful to Anil Kashyap, Chris Mayer and Julio Rotemberg for helpful comments, and to Freddie Mac for providing some of the data. We also thank Amy C. Ko, Yin-Toa Lee, and Peter Simon for research assistance. This paper is part of NBER's research program in Corporate Finance. Any opinions expressed are those of the authors and not those of the National Bureau of Economic Research.

(C) 1997 by Owen Lamont and Jeremy C. Stein. All rights reserved. Short sections of text, not to exceed two paragraphs, may be quoted without explicit permission provided that full credit, including $(\mathcal{O}$ notice, is given to the source. 
Leverage and House-Price Dynamics in U.S. Cities

Owen Lamont and Jeremy C. Stein

NBER Working Paper No. 5961

March 1997

JEL Nos. G32, R31, E44

Corporate Finance

\begin{abstract}
In this paper, we use city-level data to analyze the relationship between homeowner borrowing patterns and house-price dynamics. Our principal finding is that in cities where homeowners are more leveraged--i.e., have higher loan-to-value ratios--house prices react more sensitively to city-specific shocks, such as changes in per-capita income. This finding is consistent with recent theories which emphasize the role of collateralized borrowing in shaping the behavior of asset prices.

Owen Lamont

Graduate School of Business

University of Chicago

1101 East 58th Street

Chicago, IL 60637

and NBER

owen.lamont@gsb.uchicago.edu

Jeremy C. Stein

Sloan School of Management

Massachusetts Institute of Technology

50 Memorial Drive

Cambridge, MA 02142-1247

and NBER

jcstein@mit.edu
\end{abstract}




\section{Introduction}

This paper studies the relationship between city-level house-price dynamics and homeowner borrowing patterns. We ask the following question: is it the case that in cities where homeowners are more leveraged--in the sense of having higher loan-to-value (LTV) ratios--house prices respond more sensitively to city-specific economic shocks, such as changes in per-capita income?

In addressing this question, we take up an old and recurring theme in the literature on asset-market fluctuations, a theme which centers on the role of collateralized borrowing in shaping the behavior of asset prices. In its most general form, the proposition is that when buyers finance the purchase of assets with collateralized borrowing, this can lead the prices of these assets to become more sensitive to exogenous changes in fundamentals. Specific versions of this story have been told in the context of a variety of markets, including those for stocks (Garbade (1982)); corporate asset sales (Shleifer and Vishny (1992)); land (Kashyap, Scharfstein and Weil (1990), Kiyotaki and Moore (1995)); as well as the market which we examine here, that for houses (Stein (1995)). The common mechanism in all of these papers is that the ability to borrow is directly tied to asset values, which imparts an upward tilt to asset-demand schedules. That is, over some regions, a fall in asset prices can actually lead to reduced asset demands, because it impairs the ability of potential buyers to borrow against the assets--this is the key amplifying effect. ${ }^{1}$

\footnotetext{
'This direct two-way feedback--from asset prices to borrowing limits back to asset prices-distinguishes this particular class of models from the rest of the broader, and much larger literature on credit constraints and economic activity. Prominent examples of this latter body of work include which Fisher (1933) and Bernanke and Gertler (1989).
} 
Our decision to focus on the housing market is motivated by three considerations. First, as we argue below, housing represents an asset category where--in contrast to say, stocks--it seems a priori plausible to posit that the effect of leverage on prices might be large. A second motivation is that if house prices are in fact significantly impacted by leverage, the ultimate economic consequences are likely to be important. Topel and Rosen (1988) show that movements in prices exert a powerful influence on housing starts, and it is well-known that housing starts in turn play a major role in business-cycle fluctuations. Finally, from a practical perspective, city-level housing markets offer good data for the sort of test we wish to conduct: the markets are arguably distinct from one another; we can get reasonable price indices; and there is a good deal of variation across cities in homeowner leverage.

The remainder of the paper is organized as follows. In Section II, we articulate in more detail the theory we are testing. Section III describes our data set. Section IV contains our principal empirical results, and Section $V$ subjects these results to a range of robustness checks. Section VI concludes.

\section{Theory}

While the general story about collateralized borrowing and its effect on asset prices sounds straightforward, there are some subtleties involved in applying it to the housing market. It is perhaps easiest to see the nature of these subtleties by comparing the housing market to the stock market. In the stock market, the familiar argument is that when speculators buy stocks on margin, this creates the potential for destabilizing "pyramiding/ depyramiding" effects. The chain goes as follows: first, an initial negative shock to fundamentals knocks down prices. At 
reduced price levels, highly-levered speculators are force to dump their shares in order to meet margin calls; this forced selling in turn further depresses prices, leading to more forced selling, and so on.

Now try telling this same story, substituting "homeowner with a mortgage" for "margined-up speculator". One difference is immediately apparent. When house prices fall, the homeowner is not forced to sell his house, no matter how low his LTV ratio sinks; a typical mortgage loan does not have a margin-call feature. ${ }^{2}$ Thus a leveraged homeowner who has been hard-hit by a decline in house prices always has the option to sit tight, thereby having no effect on housing demand or supply.

So why then does homeowner leverage have any implications for house-price fluctuations? The model in Stein (1995) provides one possible answer. The model is one of repeat buyers--families who already own a home but who have reasons to want to move (e.g., new job, better schools, etc.) These families are never forced to sell their homes under adverse conditions, but may choose to if the gains from moving are large enough. In particular, at any level of house prices, families can be divided into three groups: 1) "unconstrained movers"; 2) "constrained movers"; and 3) "constrained non-movers".

Families in the first group are sufficiently wealthy that financial constraints have no effect on their behavior. Thus for them, housing demand is a decreasing function of price, and they perform a stabilizing role. Families in the second group have an intermediate level of wealth, and face binding financial constraints. In equilibrium, they each choose to sell their old house

\footnotetext{
${ }^{2}$ However, a homeowner who does not move will face difficulty in refinancing his existing mortgage at lower rates if his LTV ratio falls too far. See Caplin, Freeman and Tracy (1993) for evidence that this effect is economically important.
} 
and buy a new one, but the new one is smaller than they would like, because they do not have enough money for a larger downpayment. It is this second group that plays the crucial destabilizing role in the model, because their net demand for housing is an increasing function of price: if house prices were to rise, a constrained-mover family would be able to realize more from the sale of their old house, and use this to make a downpayment on a larger new house. Finally, families in the third group are so wealth-constrained that in spite of the potential gains from moving, they are better off sitting tight, as discussed above. Thus they neither buy nor sell, and have no effect at all on house prices. ${ }^{3}$

The key implication that follows from this line of reasoning is that in order for leverage effects to have meaningful consequences for house prices, there must be a relatively high ratio of constrained movers to unconstrained movers in the population. This occurs when a large fraction of homeowners are packed into a narrow range of "high" LTV ratios, where "high" represents a value--perhaps $80 \%$ or so--where downpayment constraints begin to become binding. Thus in testing the theory empirically, we would ideally like a measure of leverage at the city level that captures this "packing" concept. That is, something like the median LTV ratio in a city is not the most theoretically desirable measure; it would be better to have something like the percentage of homeowners with LTV's in excess of $80 \%$.

Subject to this "packing" condition being met, simulations in Stein (1995) suggest that the impact of fundamental shocks on house prices can be greatly magnified relative to the benchmark case of no financial constraints. The reason that leverage can matter so much in the

\footnotetext{
${ }^{3}$ Although they have no effect on equilibrium prices in this model, constrained-non-mover families are central to understanding another important housing-market phenomenon: the fact that trading volume is strongly correlated with prices.
} 
housing market is that the potential for stabilizing arbitrage is limited. Again, the contrast with the stock market is instructive. In spite of its surface appeal, the stock-market story of margin "pyramiding/depyramiding" has been subject to a great deal of skepticism. ${ }^{4}$ The root of this skepticism is the idea that stabilizing arbitrage should be relatively easy in the stock market: all it takes to cut off a downward leverage-induced spiral in stock prices is a small set of relatively risk-tolerant arbitrageurs who are not credit-constrained. In contrast, this basic arbitrage argument has much less force in the housing market: if house prices begin to drop, it is unlikely that a small set of arbitrageurs will buy up a large chunk of the housing stock, because unlike with equities, there are obvious diminishing returns to owning more than one house. ${ }^{s}$

Before proceeding, we should highlight two caveats. On the conceptual front, while the model in Stein (1995) is useful in motivating our tests, and giving some qualitative guidance on the choice of variables, it also suffers from a crucial weakness for our purposes, in that it is static. Thus all the model really predicts is that prices will, in some timeless sense, react "more" to fundamental shocks in high-leverage cities; it is silent on the dynamic nature of the adjustment process. In other words, the model provides no guidance for thinking about whether any price discrepancies between otherwise identical high- and low-leverage cities ought to open up quickly or slowly in response to fundamental shocks, be long-lived or eventually decay away,

${ }^{4}$ To get a feel for the debate over whether margin borrowing destabilizes stock prices, see, e.g., the exchange between Hardouvelis (1990) and Hsieh and Miller (1990).

${ }^{5}$ Similarly, Shleifer and Vishny (1992) offer a reason why arbitrage will have limited stabilizing effect in the corporate asset sales market: those potential buyers who are most likely to be unaffected by adverse shocks to a given industry, and hence to be financially unconstrained in a downturn, are industry outsiders, who simply cannot extract as much value from the assets in question. See Pulvino (1995) for evidence from the airline industry that supports this view. 
etc. Since our empirical work must inevitably confront these dynamic issues, we cannot claim that we are disciplined by a fully articulated theoretical model.

In terms of statistical inference, our biggest potential pitfall arises out of the fact that any measure of leverage at the city level, no matter how well it corresponds to the underlying theory, is endogenous. To see how this might cause problems, consider the following alternative story, which we label the "emerging-city hypothesis". ${ }^{6}$ The premise of this story is that some cities are in the process of undergoing fundamental transitions. Moreover, such transitions are purported to have two distinct effects. First, they are accompanied by increased migration into the city. This migration in turn impacts city measures of leverage; for example, it is plausible that newcomers to a city will buy homes with higher loan-to-value ratios, perhaps because they tend to be younger and thus have accumulated less wealth. ${ }^{7}$

Second, for cities in the process of transition, current economic shocks such as changes in per-capita income contain more information about future growth prospects. Consequently, forward-looking asset prices such as house prices should rationally respond by more to these economic shocks. If these two assertions are both correct, there will be an induced correlation between city measures of leverage and the sensitivity of house prices to income shocks, even if leverage plays no causal role. We do our best to distinguish between this emerging-city alternative hypothesis and our leverage-based hypothesis in Section V.C.

\footnotetext{
${ }^{6}$ We thank Anil Kashyap for pointing out this alternative hypothesis to us.

'Indeed, as we will see below, the data support the idea that increases in a city's population growth are associated with higher levels of homeowner leverage.
} 


\section{Data Sources}

Our data on borrowing patterns at the city level come from the American Housing Survey (AHS) for 44 metropolitan areas between 1984 and 1994. The AHS is administered jointly by the Bureau of the Census and HUD. Each city is survey approximately once every four years; every year 11 cities are surveyed. The cities surveyed are Anaheim, Atlanta, Baltimore, Birmingham, Boston, Buffalo, Chicago, Cincinnati, Cleveland, Columbus, Dallas, Denver, Detroit, Fort Worth, Hartford, Houston, Indianapolis, Kansas City, Los Angeles, Memphis, Miami, Milwaukee, Minneapolis, New Orleans, New York, Norfolk, Northern NJ, Oklahoma City, Philadelphia, Phoenix, Pittsburgh, Portland, Providence, Riverside, Rochester, Salt Lake City, San Antonio, San Diego, San Francisco, San Jose, Seattle, St. Louis, Tampa, and Washington.

In each city survey, data from several thousand randomly selected households are obtained. Among other questions, the AHS asks homeowners whether they have one (or more) mortgage(s), and what the monthly payments and other terms of the mortgage(s) are. Using the owner-reported terms of the mortgage, the AHS calculates the principal remaining on the mortgage; using this estimate of the principal and what the owner estimates to be the market value of the property, the AHS then calculates LTV ratios. ${ }^{8}$

Drawing on the summary statistics published by the AHS, we are able to obtain several different measures of leverage at the city level. The first, which we call PACK, is the fraction of all owner-occupants with LTV ratios exceeding $80 \%$. We use $80 \%$ as a cutoff because it is

${ }^{8}$ Homeowners' estimates of the value of their own home, while biased upwards, do not appear to be related to the characteristics of the owner, the house, or the local housing market. See Goodman and Ittner (1992). 
a standard benchmark for "excessive" LTV ratios, used for example to determine private mortgage insurance requirements. As discussed above, the PACK measure probably comes closest to capturing the relevant theoretical construct in Stein (1995)--namely the extent to which a city has a large fraction of the population "packed" into a narrow range of high LTV's.

One potential problem with PACK is that its value might be quite sensitive to any errors homeowners make in estimating the value of their homes. In light of this concern, we also work with two other measures which are likely to be more robust to such errors: YESMTG, the fraction of all owner-occupants having a mortgage of any size; and MEDIAN, the median LTV ratio among those owner-occupants who have a mortgage.

Table 1 gives some basic summary statistics for our three leverage measures. On average across the entire sample, $66 \%$ of homeowners have mortagages. Among these mortgage holders, the median LTV ratio is $52 \%$. Of all homeowners, $14 \%$ have LTV's exceeding the $80 \%$ threshhold. Fortunately for our purposes, there is also a good deal of variation across cities in the leverage measures. For example, the PACK variable ranges from a min of $3 \%$ in Northern New Jersey in 1986 to a max of $35 \%$ in Denver in 1989. Similarly, the median LTV ranges from a min of $24 \%$ to a max of $75 \%$, with the same two cities representing the extreme points. 9

The bottom half of Table 1 also investigates the extent to which our three leverage measures are correlated with one another. The correlation between PACK and MEDIAN is very high, at .89. PACK is also quite correlated with YESMTG, with a coefficient of .46. The

\footnotetext{
${ }^{9}$ For New York City in 1986, leverage was so low that the AHS did not report either MEDIAN, or the data needed to construct PACK. We thus omit this observation, except when using the YESMTG measure of leverage.
} 
weakest correlation is between MEDIAN and YESMTG, at .30.

The AHS-derived leverage measures are only available for each city at four-year intervals. Other metropolitan-area variables are available annually. For house prices, we use the Conventional Mortgage Home Price Index, jointly created by researchers at Freddie Mac and Fannie Mae using repeat-sales prices from mortgage transactions. ${ }^{10}$ For population and income per capita, we use data from the Bureau of Economic Analysis. In all cases, we deflate nominal variables by the aggregate US CPI index to obtain real values, and compute annual changes by taking log differences. Table 1 also provides some summary statistics for our data on house prices, demographics and income.

Given that we wish to exploit the annual data that we have on house prices, income and demographics, the once-every-four-year nature of the AHS survey represents a substantial weakness. There are two basic approaches that we can take to deal with this problem. In most of our analysis, we use a "stale data" method: we run annual regressions, and in each city-year use for a leverage variable the most recent value which we have for that city. This means that at any point in time, we can have a leverage measure that is as much as three years out of date. Because the staleness of the data effectively amounts to measurement error, we would expect that this approach would yield downward-biased estimates of the impact of leverage on houseprice dynamics--i.e., our estimates using this approach are likely be too conservative.

In an effort to mitigate this potential bias, we also experiment with an alternative

${ }^{10}$ One concern with this sort of repeat-sales price index is that it may generate price changes that are spuriously positively correlated over time. This does not pose too much of a problem for the particular sort of tests that we conduct below, but it may badly confound other related analyses--e.g., attempts to measure the volatility of house prices. See Section IV.C below for a full discussion of these issues. 
"projected data" method. The idea here is to use the annual series that we do have available to create annual projected values of our leverage variables, and to use these projected values in place of the stale data. As one would expect, this method tends to boost our estimates of the importance of leverage.

\section{Empirical Results}

\section{A. A Benchmark Model of House-Price Dynamics}

Our ultimate goal is to see how house-price dynamics vary across cities with different measures of homeowner leverage. But before we can do this, we need to select a benchmark model of city-level house-price dynamics. Ideally, this model should capture in a simple and robust way three key features of house prices that have been repeatedly documented in prior empirical work: 1) prices respond to contemporaneous economic shocks; 2) there are short-run "momentum" effects; and 3) there is a long-run tendency for "fundamental reversion"."

Table 2 details our search for a benchmark specification. There are six columns. In each one, we regress annual house price appreciation at the city level--denoted by $\mathrm{dP}_{\mathrm{t}}$--on some combination of the following six right-hand-side variables: the contemporaneous change in percapita income $\mathrm{dI}_{t}$, and two of its lagged values, $\mathrm{dI}_{\mathrm{t}-1}$ and $\mathrm{dI}_{\mathrm{t}-2}$; two lagged price appreciation terms, $\mathrm{dP}_{\mathrm{t}-1}$ and $\mathrm{dP}_{\mathrm{t}-2} ;$ and the start-of-period ratio of price to per-capita income, $\mathrm{P}_{\mathrm{t}-1} / \mathrm{I}_{\mathrm{t}-1}$. All the regressions also include fixed effects for each year and each city, so that we are always working with deviations from both: national averages in any year; and long-run city averages. (The data

\footnotetext{
"See, e.g., Case and Shiller (1989, 1990), Cutler, Poterba and Summers (1991), Poterba (1991) and Abraham and Hendershott (1994) for empirical models of house-price dynamics.
} 
strongly reject the hypothesis that these year and city dummy variables do not belong).

Column (1) shows that in a univariate regression, the elasticity of prices with respect to contemporaneous income is about .8. This univariate regression achieves an adjusted $\mathbf{R}^{2}$ of .34 . In columns (2)-(5), we begin adding in the other variables. These tend to reduce the coefficient on the contemporaneous income term $\mathrm{dI}_{t}$, but substantially enhance the explanatory power of the regression. Column (5) shows that when all six variables are used simultaneously, the adjusted $R^{2}$ rises to .74 . However, in this regression, only three variables-- $d L_{t}, d_{t-1}$, and $P_{t-1} / I_{t-1}-$ are statistically significant. The other variables are apparently subsumed by these three.

This suggests that we can do almost as well with a more parsimonious specification which uses only the three most important variables from column (5). This sparer regression is run in column (6). As can be seen, there is no loss in explanatory power to speak of--the adjusted $\mathbf{R}^{2}$ remains at .74. The coefficient on $\mathrm{dI}_{\mathrm{t}}$ is .356; that on $\mathrm{dP}_{\mathrm{t}-1}$ is .495; and that on $\mathrm{P}_{\mathrm{t}-1} / \mathrm{I}_{\mathrm{t}-1}$ is -.195 . This three-variable model captures nicely and simply the three features of house prices alluded to above: 1) sensitivity to contemporaneous shocks (the $\mathrm{dL}$ term); 2) short-run momentum (the positive $\mathrm{dP}_{t-1}$ term); and 3) long-run fundamental reversion (the negative $P_{t-1} / I_{t-1}$ term).

To illustrate this point, Figure 1 depicts the impulse response of house prices to a permanent one-percent increase in per-capita income, using the parameter estimates from column (6) of Table 2. ${ }^{12}$ As can be seen from the figure, the first year's effect on house prices is .36 percent. This increase then feeds positively into the next year's prices both by raising the lagged

\footnotetext{
${ }^{12}$ Preliminary analysis suggests that income shocks at the city level are in fact permanent-i.e., that income roughly follows a random walk. In particular, when we run the change in income on the city and year dummies and two lags of the change in income, the coefficients on these first two lags are $0.13(\mathrm{t}$-stat $=1.3$ ) and $0.02(\mathrm{t}$-stat $=0.3$ ) respectively.
} 
price change term and lowering the price-to-income term. After about four years, the adjustment is complete, so that house prices have risen one percent and are back in line with income levels. $^{13}$

From this point forward, we use the three-variable specification in column (6) of Table 2 as our baseline. Everything that follows asks in one way or another whether some or all of the coefficients in this simple model are related to the measures of leverage.

\section{B. The Impact of Leverage}

Table 3 presents a first test of our central hypothesis. We begin with the three-variable specification, and add a single interaction term, given by $\mathrm{dI}_{\mathrm{t}}{ }^{*} \mathrm{DEBT}_{\mathrm{t}-1}$, where $\mathrm{DEBT}_{\mathrm{t}-1}$ is a oncelagged leverage measure. In column (1) we use PACK as the leverage measure; in column (3) we use YESMTG; and in column (5) we use MEDIAN. In words, we are asking if prices are more sensitive to contemporaneous income shocks in high-leverage cities.

As can be seen from the table, the answer to this question appears to be yes. Whichever measure of leverage is used, the interaction terms are always positive and statistically significant. Moreover, the magnitude of the leverage effect is quite large in economic terms. This is perhaps easiest to see by comparing the impulse response of house prices to an income shock for cities with different leverage levels. This is done in Figure 2. The figure uses the parameter

\footnotetext{
${ }^{13}$ By including the lagged price-to-income ratio on the right-hand side of the equation, we are implicitly imposing the assumption that the long-run elasticity of prices with respect to cityspecific income shocks is one. Empirical evidence in Poterba (1991) suggests that this is not unreasonable. Note, however, that because we have city and year dummies, we do allow for: 1) different cities to have different average price-income ratios (perhaps due to variations in land availability, etc.); and 2) general trends in national price-income ratios (perhaps due to changes in the tax code, demographics, etc.).
} 
estimates from column (1) of Table 3 , and compares a city with the 10 th percentile value of PACK (which is approximately 5\%) to a city with the 90th percentile value of PACK (which is approximately $25 \%$ ).

The figure depicts a dramatic difference in the implied reaction of the two cities to a $1 \%$ income shock. In the high-leverage city, prices are up by $.64 \%$ in the first year, as compared to only $.19 \%$ in the low-leverage city. By the third year, the corresponding cumulative price movements are $1.23 \%$ and $.68 \%$. Thus in the high-leverage city, prices actually overshoot their new long-run value by a substantial margin. This overshooting reaches a peak in the fourth year, when the price increase hits $1.29 \%$ in the high-leverage city, before turning around.

As a slight variation on the specifications in columns (1), (3), and (5) of Table 3, we also tried including the lagged measure of leverage $\mathrm{DEBT}_{\mathrm{t}-1}$ itself in the regression as an additional control variable. This is done in columns (2), (4) and (6) of the table. To some extent, leverage represents the outcome of an endogenous choice on the part of borrowers and lenders. If these agents are forward-looking, they may be more willing to enter into high-LTV loans when house prices are expected to rise. Thus one might expect higher values of leverage to predict higher price appreciation. Indeed, for all three of our measures, high leverage today is positively correlated with future price appreciation; this conditional correlation is strongest (and either statistically significant or close to it) for those two measures that directly capture high LTV ratios, PACK and MEDIAN. However, for our purposes the important point is that including this extra variable in the regression does not materially change the estimated coefficients on the key $\mathrm{dI}_{\mathrm{t}}{ }^{*} \mathrm{DEBT} \mathrm{T}_{\mathrm{t}-1}$ interaction term.

One concern with the regressions in Table 3 is that they are very tightly parametrized. 
First of all, they allow only the $\mathrm{dL}_{1}$ coefficient to vary with leverage, and force the $\mathrm{dP}_{\mathrm{t}-1}$ and $P_{t-1} / I_{t-1}$ coefficients to be constant. Second, they impose a linear relationship between the leverage measures and the $\mathrm{dl}_{\mathrm{t}}$ coefficient. Since some of these restrictions may not be warranted, we experiment in Table 4 with a much more loosely specified version of the same basic test. We now divide our sample up into quartiles, sorted on the leverage variable $\mathrm{DEBT}_{\mathrm{t}-1}$, and run separate versions of the benchmark regression from column (6) of Table 2 for each quartile. The table reports the results for the top and bottom quartiles, using sorts based on each of our three definitions of leverage.

Three basic conclusions emerge from Table 4. First, prices still seem to respond more sensitively to income shocks in high-leverage cities: the coefficient on $\mathrm{dL}_{4}$ is always substantially larger in the high-leverage quartile. Moreover, even with the loss in statistical power that this method entails, the difference is strongly significant for the YESMTG measure of leverage, and marginally significant for the PACK measure. Second, there is much less of a discernible pattern across quartiles in terms of the coefficients on $\mathrm{dP}_{t-1}$ and $P_{t-1} / I_{t-1}$. For example, the coefficient on $\mathrm{dP}_{\mathrm{t}-1}$ is about the same across quartiles when we use PACK; is higher in the highleverage quartile when we use YESMTG; and is lower in the high-leverage quartile when we use MEDIAN.

Finally, consistent with these first two observations, the regressions in Table 4 yield impulse response functions that look quite similar to those implied by the regressions in Table 3. This is illustrated in Figure 3, which plots the impulse responses for the high and low 
quartiles according to our PACK measure of leverage. ${ }^{14}$ The only noteworthy difference from Figure 2 is that while the high-leverage city still reacts much faster to an income shock, it no longer overshoots its new long-run value. Overall then, the two types of specifications point to the same basic conclusions.

\section{Implications for House-Price Volatility?}

At first glance, it might appear that the regression results in Table 3--wherein highleverage cities have a higher coefficient on $\mathrm{dI}_{\mathrm{t}}-$-would imply that the volatility of house prices is greater in these cities. However, this simple intuition is not generally correct. It does hold in the special case where the regression coefficients on $\mathrm{dP}_{\mathrm{t}-1}$ and $\mathrm{P}_{\mathrm{t}-1} / \mathrm{I}_{\mathrm{t}-1}$ are equal to zero; in this univariate case with no dynamics, a greater sensitivity to the one driving variable $\mathrm{dI}_{\mathrm{l}}$ is obviously equivalent to greater volatility (assuming that this driving variable itself follows the same process across different cities). ${ }^{15}$ But when the coefficients on $\mathrm{dP}_{\mathrm{t}-1}$ and $\mathrm{P}_{\mathrm{t}-1} / \mathrm{I}_{\mathrm{t}-1}$ are non-zero, one can show that there is not necessarily any direct relationship between the coefficient on $\mathrm{dI}_{\mathrm{t}}$ and the volatility of house prices.

This result can be better understood by reference to Figure 2 . In this figure, we see what might be termed sluggish reaction for the low-leverage city, in the sense that it takes prices several periods to adjust to an income shock. Now loosely speaking, to the extent that

${ }^{14}$ Figure 3 is more or less directly comparable to Figure 2, because the midpoints of the bottom and top quartiles in Figure 3 are the 12.5th and 87.5th percentiles respectively, whereas in Figure 2 we defined low and high leverage as the 10th and 90th percentiles respectively.

${ }^{15}$ This simple case is essentially what emerges out of the theoretical model in Stein (1995). Because the model is a static one, there is a direct correspondence between sensitivity to contemporaneous fundamentals and volatility. 
increasing the coefficient on $\mathrm{dL}_{t-1}$ accelerates the reaction without going so far as to generate "too much" overshooting, it can actually lead to a less volatile price series.

Consistent with this line of reasoning, we find little direct empirical evidence in support of the hypothesis that house prices are more volatile in high-leverage cities. For example, when we regress the absolute house-price change in a city on our various measures of city leverage (as well as on the city and year dummies), we obtain point estimates that are very close to zero and statistically insignificant.

How should one interpret the fact that leverage seems to make house prices more sensitive to fundamentals, yet not more volatile? Although one can tell a variety of economic stories, we should caution that this phenomenon might also be simply the outcome of measurement error in our house-price indices. ${ }^{16}$ As Case and Shiller (1989) emphasize, the way that repeat-sales type indices are constructed can induce spurious positive serial correlation in house-price changes. In other words, the positive coefficient on $\mathrm{dP}_{\mathrm{t}-1}$ that we document in our regressions--and hence the sluggish reaction that we portray, e.g., for the low-leverage cities in Figure 2--may be partially an artifact of the data, and not a true characteristic of house prices. ${ }^{17}$

Similarly, our failure to find significant differences in house-price volatility across high and low-leverage cities may also be due to the artificially smoothed nature of our house-price series. Indeed, if measurement error in the house-price indices is a problem, it is

\footnotetext{
${ }^{16}$ In the conclusion, we discuss one possible story, rooted in the idea that housing-market participants are irrational and have a tendency--absent leverage effects--to underreact in the short-term to news about fundamentals.

${ }^{17}$ However, it should be pointed out that even after correcting for this spurious correlation, Case and Shiller (1989) still find some residual tendency for sluggish reaction in house prices. They interpret this as evidence of market inefficiency.
} 
straightforward to argue that we are better off doing as we have been in Tables 3 and 4 , and trying to make inferences about the sensitivity of prices to fundamentals, as opposed to inferences about the volatility of prices. $^{18}$

\section{Robustness Issues}

Next, we investigate the extent to which our results are robust to several variations in estimation technique. The tests we conduct below represent modifications of our more tightlyparametrized specification from Table 3. We have also examined the analogous modifications of the looser specification in Table 4; as one might expect based on the comparisons above, these yield very similar conclusions, so in the interests of brevity, we do not report them.

\section{A. Qutliers}

Table 5 checks whether the results in Table 3 are due primarily to a few influential outliers. We sort the observations on both $\mathrm{dP}_{\mathrm{t}}$ and $\mathrm{dI}_{t}$, and discard the top and bottom one percent of the realizations for these two variables. As can be seen from Table 5, this actually results in a fairly substantial increase in the $\mathrm{dI}_{\mathrm{t}}^{*}$ DEBT $\mathrm{t}_{\mathrm{t}-1}$ interaction coefficients in both the PACK and MEDIAN-based specifications. The point estimates in the YESMTG case are somewhat reduced, but still statistically significant. In sum, it seems clear that our results are not due to a handful of outliers, but rather reflect the central tendencies of the data.

\footnotetext{
${ }^{18}$ In a univariate regression of $\mathrm{dP}_{\mathfrak{t}}$ on $\mathrm{dI}_{\mathfrak{t}}$, measurement error in $\mathrm{P}_{\mathrm{t}}$ would cause no bias at all in the estimated coefficient, since it is on the left-hand side of the equation.
} 


\section{B. Correcting for Stale Leverage Data}

As noted above, the AHS survey occurs only once every four years for a given city, so that in our work with annual data, we often have outdated measures of leverage. Thus far we have more or less ignored the problem, using the stale data with no adjustments. We now try to do better. One approach is to construct an annual proxy for leverage using the four-year AHS data and other data that we have available annually. In doing so, we do not want to simply interpolate the four-year data, since this could potentially make the constructed leverage variable at any point in time contain information about future price movements. ${ }^{19}$

Instead, for the approximately 110 city-years in which we do have fresh measures of leverage, we run a "kitchen sink" first-stage regression of leverage on the start-of-period priceto-income ratio, as well as on current and once-lagged values of: house price changes; growth in income per capita; and population growth. Using the estimated coefficients from this regression, we then can construct an annual projected leverage measure for each city and year. The advantage of this approach is that the projected leverage measure at any time $t$ now only contains information available at that time. ${ }^{20}$

Table 6 shows the results of the kitchen sink regressions, for each of our three leverage measures. With seven explanatory variables, the adjusted $\mathrm{R}^{2}$ 's range from .31 to .46 . Many of the right-hand-side variables are statistically insignificant, but three emerge quite clearly as

\footnotetext{
${ }^{19}$ To see why, suppose we proxy for PACK in year $t+2$ by averaging observations of PACK at $t$ and $t+4$. The value of PACK at $t+4$ may contain information about price movements after $t+2$--e.g., if a sharp price rise in year $t+3$ reduces LTV's in subsequent years.

${ }^{20}$ Except, of course, to the extent that the regression coefficients themselves are based on data from the entire sample period.
} 
important: 1) lagged income growth, which has a negative net effect on leverage; 2) population growth, which has a positive net effect; and 3) the price-to-income ratio, which has a negative effect. The positive population-growth effect is particularly noteworthy, as it lends some credence to the "emerging-city" hypothesis discussed above--cities that are experiencing abnormally high levels of inward migration do seem to have higher homeowner leverage. We will return to this point shortly.

In Table 7, we re-run the regressions of Table 3, but substitute in our projected leverage measures for the actual stale data. As one might have expected based on the idea that we are fixing a measurement error problem, the coefficients on the key $\mathrm{dL}_{\mathrm{t}}{ }^{*} \mathrm{DEBT} \mathrm{T}_{\mathrm{t}-1}$ term increase in all six specifications. In many cases, the magnitude of this increase is quite substantial. For example, in the column (1) specification using the PACK measure, the coefficient of interest rises from 2.27 in Table 3 to 3.03 in Table 7 , an increase of approximately $33 \%$. Figure 4 redoes our impulse response comparison from Figure 2, now using the newly estimated coefficients from column (1) of Table 7. The implied differences between the high- and lowleverage cities are now even more pronounced than before.

\section{Addressing the Emerging-City Hypothesis}

While all the results to this point are consistent with the hypothesis that leverage has a causal impact on house-price dynamics, there is also an alternative interpretation, based on the emerging-city hypothesis. Recall that the idea here is that there are some transitioning cities which have two key traits: 1) they are experiencing above-average population growth, which leads to higher measures of leverage; and 2) their shocks to per-capita income are relatively 
more informative about long-run city prospects.

We now make a couple of attempts to distinguish between our leverage-based hypothesis and this alternative. One approach is to assume that the extent to which a city can be characterized as "emerging" is more or less fixed over the 10-year duration of our sample period. If this identifying assumption is correct, we can completely control for the emergingcity phenomenon, by using a city fixed-effects approach--i.e., by only looking at the effects of within-city variations in leverage, and dummying out across-city variations. ${ }^{21}$

We implement this approach in Table 8. The specifications are the same as in Table 3, except that we allow each of the 44 cities to have its own coefficient on $\mathrm{dI}_{4}$. Thus if some cities are more "emerging" than others over the entire sample, and hence have house prices that are more sensitive to income shocks, this will now be picked up in the city-specific $\mathrm{dI}_{1}$ coefficients, and not in the $\mathrm{dI}_{t}{ }^{*} \mathrm{DEBT}_{\mathrm{t}-1}$ interaction term. As it turns out, this does not reduce the interaction coefficients. In fact, in five of six cases, the interaction terms increase relative to Table 3 , in some cases by quite a bit. Naturally, by removing all the across-city variation in our leverage measures, we reduce the precision of our estimates. Still, the interaction coefficients remain statistically significant in three of the six specifications.

One objection to this methodology is that the "emerging" characteristic is not fixed for cities over the entire 10-year sample period. For example, a city that was not emerging in 1984 may begin to emerge in 1990. If this is the case, things become more difficult. Because we do

\footnotetext{
${ }^{21}$ It should be emphasized that the city fixed effects that we have in mind here are above and beyond those already in the baseline model. In other words, we have already allowed the average degree of price appreciation to vary city-by-city; now we are proposing to allow the sensitivity of prices to income to also vary city-by-city.
} 
not have perfectly exogenous instruments for leverage, the best we can do is to control directly for any observable variables that are likely to proxy for the extent to which a city is emerging. One such candidate variable that we have already discussed is population growth.

In Table 9, we run a horse race which effectively asks: are our previous interaction results truly due to leverage effects, or merely to the fact that leverage is correlated with population growth, which is in turn a proxy for "emergingness"? The regressions are similar to those in Table 3, with the following modifications. In columns (1), (3) and (5), we add a second interaction term, $\mathrm{dI}_{1}{ }^{*} \mathrm{dPOP}_{\mathrm{t}-1}$, where $\mathrm{dPOP}_{\mathrm{t}}$ is defined as a city's population growth in the year from $t-1$ to $t$. In columns (2), (4) and (6), we also add $\mathrm{dPOP}_{t-1}$ by itself. Thus we treat the APOP variable exactly symmetrically to the DEBT variable, and let the data tell us which one better explains variation in the coefficient on $\mathrm{dI}_{t}$. The answer is clear-cut. The interaction terms involving $\mathrm{dPOP}_{t-1}$ are completely insignificant, while those involving $\mathrm{DEBT}_{\mathrm{t}-1}$ are almost exactly identical to the ones in Table 3 .

Overall, Tables 8 and 9 are good news for the proposition that leverage exerts a causal influence on house-price dynamics. Of course we recognize that because we do not have perfect instruments for leverage, the possibility remains that this inference is muddled by some as-yet unspecified endogeneity problem. But to the extent that we have been able to formulate two concrete and testable versions of an alternative hypothesis--i.e., the emerging-city hypothesis-this particular explanation of our findings has been shot down.

\section{Conclusions}

Our empirical results are compactly summarized by the sort of impulse responses 
depicted in Figure 2. The reaction of house prices to income shocks is markedly different across high- and low-leverage cities. In high-leverage cities, our baseline estimates suggest not only that prices react quite quickly to an income shock, but also that the magnitude of the reaction is so large that it entails a substantial temporary overshooting of prices relative to their new-long level. In contrast, the price reaction in low-leverage cities is much more gradual, and there is no overshooting to speak of. These differences are robust to a range of variations in estimation technique. Moreover, to the best of our ability to sort it out, it appears that the relationship reflects causality running from leverage to house prices, as opposed to a spurious byproduct of the endogeneity of our city-level measures of leverage.

These results are consistent with the broad spirit of recent theoretical models that emphasize how collateralized borrowing can make asset prices more sensitive to fundamental shocks. At the same time, the results also serve to underscore weaknesses in some of the existing models. In particular, the empirical phenomenon documented in this paper is an inherently dynamic one: as can be seen in Figure 2, the price gap between a high- and lowleverage city widens in the first couple of years after an income shock, and then gradually narrows after that. In contrast, the model of the housing market in Stein (1995) is static, and thus cannot capture this dynamic adjustment process. Thus one clear direction for future research involves building explicitly intertemporal models of house prices that can both accomodate leverage effects and at the same time generate empirically plausible price dynamics.

In this regard, there are two quite different approaches that one might take. On the one hand, one might try to stick within the confines of a fully rational model that--as in Kiyotaki and Moore (1995)--incorporates both intertemporal considerations and collateralized borrowing. It 
is not yet clear to us at this point how far such a model will be able to go in terms of rationalizing the specific kinds of impulse responses seen in Figure 2.

Alternatively, one might superimpose leverage effects on top of a "behavioral" model of house-price dynamics. That is, one might begin by accepting the interpretation of Case and Shiller (1989, 1990), Cutler, Poterba and Summers (1991), and many others, who suggest that the short-run momentum and long-run fundamental reversion seen in house prices reflects an irrational speculative phenomenon. The question would then be how homeowners' debt positions either temper or amplify these baseline speculative inefficiencies. Interestingly, in this sort of model, there might be cases where leverage actually has a net beneficial effect on housingmarket efficiency. For example, if the gradual price adjustment seen in low-leverage cities reflects the fact that market participants systematically underreact in the short run to news about fundamentals, then to the extent that homeowner leverage accelerates the reaction of prices, it might be helping to make the market more efficient. 


\section{$\underline{\text { References }}$}

Abraham, Jesse M. and Patric H. Hendershott, "Bubbles in Metropolitan Housing Markets," Ohio State working paper, 1994, forthcoming in Journal of Housing Research.

Bernanke, Ben S. and Mark Gertler, "Agency Costs, Net Worth, and Business Fluctuations," American Economic Review, March 1989, 79, 13-31.

Caplin, Andrew, Charles Freeman and Joseph Tracy, "Collateral Damage: How Refinancing Constraints Exacerbate Regional Recessions," NBER working paper 4531, 1993.

Case, Karl E. and Robert J. Shiller, "The Efficiency of the Market for Single-Family Homes," American Economic Review, March 1989, 79, 125-37.

Case, Karl E. and Robert J. Shiller, "Forecasting Prices and Excess Returns in the Housing Market," AREUEA Journal, 1990, 18, 253-73.

Cutler, David M., James M. Poterba and Lawrence H. Summers, "Speculative Dynamics," Review of Economic Studies, 1991, 58, 529-46.

Fisher, Irving, "The Debt Deflation Theory of Great Depressions", Econometrica, October 1933, 1, 337-357.

Garbade, Kenneth D., "Federal Reserve Margin Requirements: A Regulatory Initiative to Inhibit Speculative Bubbles," in Paul Wachtel ed., Crises in Economic and Financial Structure, Lexington, MA: Lexington Books, 1982.

Goodman, John L. Jr., and John B. Ittner, "The Accuracy of Home Owners' Estimates of House Value," Journal of Housing Economics, 1992, 2, 339-357.

Hardouvelis, Gikas A., "Margin Requirements, Volatility, and the Transitory Component of Stock Prices," American Economic Review September 1990, 80, 736-62.

Hsieh, David A. and Merton H. Miller, "Margin Regulation and Stock Market Volatility," Journal of Finance, March 1990, 45, 3-29.

Kashyap, Anil, David Scharfstein and David Weil, "The High Price of Land and the Low Cost of Capital: Theory and Evidence from Japan," MIT working paper, 1990.

Kiyotaki, Nobuhiro and John H. Moore, "Credit Cycles," NBER working paper 5083, 1995. 
Poterba, James M., "House Price Dynamics: The Role of Tax Policy and Demography," Brookings Papers on Economic Activity, 1991, 143-183.

Pulvino, Todd, "Do Asset Fire-Sales Exist? An Empirical Investigation of Commercial Aircraft Transactions," Harvard working paper, 1995.

Shleifer, Andrei and Robert W. Vishny, "Liquidation Values and Debt Capacity: A Market Equilibrium Approach," Journal of Finance, September 1992, 47, 1343-1366.

Stein, Jeremy C., "Prices and Trading Volume in the Housing Market: A Model With Downpayment Effects," Quarterly Journal of Economics, May 1995, 110, 379-406.

Topel, Robert and Sherwin Rosen, "Housing Investment in the United States" Journal of Political Economy, 1988, 96, 718-40. 
Table 1: Summary Statistics, 44 cities, 1985-1994

\begin{tabular}{|l|l|l|l|l|l|}
\hline & Description & Mean & $\begin{array}{l}\text { Std } \\
\text { Dev }\end{array}$ & Min & Max \\
\hline House Prices & & & & & \\
\hline DNOMPRICE & Nominal Price Change & 0.03 & 0.05 & -0.11 & 0.27 \\
\hline DCPI & $\begin{array}{l}\text { Inflation (National CPI, Year } \\
\text { Average) }\end{array}$ & 0.04 & 0.01 & 0.02 & 0.05 \\
\hline DP & Real Price Change & -0.01 & 0.05 & -0.13 & 0.23 \\
\hline Mortgage & & & & & \\
\hline PACK & Percent with L/V > 8 & 0.14 & 0.07 & 0.03 & 0.35 \\
\hline YESMTG & Percent Having MTG & 0.66 & 0.08 & 0.44 & 0.80 \\
\hline MEDIAN & MEDIAN of all MTGs & 0.52 & 0.12 & 0.24 & 0.75 \\
\hline $\begin{array}{l}\text { Demographics } \\
\text { and Income }\end{array}$ & & & & & \\
\hline DNOMINC & Nominal Change in Inc Per Cap & 0.05 & 0.02 & -0.03 & 0.12 \\
\hline DI & Real Change in Inc Per Cap & 0.01 & 0.02 & -0.05 & 0.07 \\
\hline DPOP & Change in Population & 0.01 & 0.01 & -0.01 & 0.07 \\
\hline
\end{tabular}

Correlation Matrix

\begin{tabular}{|l|l|l|}
\hline & PACK & YESMTG \\
\hline YESMTG & 0.46 & 1 \\
\hline MEDIAN & 0.89 & 0.30 \\
\hline
\end{tabular}




\section{Table 2: Real House Prices and Real Income}

$\begin{array}{lllllll} & (1) & (2) & (3) & (4) & (5) & (6) \\ \mathrm{DI}_{\mathrm{t}} & 0.813 & 0.484 & 0.298 & 0.268 & 0.426 & 0.356 \\ & (5.05) & (3.17) & (2.49) & (1.98) & (3.32) & (3.49) \\ \mathrm{DI}_{\mathrm{t}-1} & & 0.553 & & 0.296 & 0.161 & \\ & & (3.17) & & (1.79) & (1.42) & \\ \mathrm{DI}_{\mathrm{t}-2} & & 0.275 & & -0.038 & -0.105 & \\ & & (2.22) & & (0.33) & (1.31) & \\ \mathrm{DP}_{\mathrm{t}-1} & & & 0.737 & 0.718 & 0.530 & 0.495 \\ & & & (8.37) & (8.33) & (7.19) & (9.59) \\ \mathrm{DP}_{\mathrm{t}-2} & & & -0.165 & -0.179 & -0.003 & \\ & & & (2.166) & (2.88) & (0.06) & \\ \mathrm{P}_{\mathrm{t}-1} / \mathrm{I}_{\mathrm{t}-1} & & & & & -0.220 & -0.195 \\ & & & & & (6.83) & (8.08) \\ & & & & & & \\ \text { No. of Obs } & 418 & 330 & 330 & 330 & 330 & 374 \\ \text { Adj. R2 } & & & & & & \\ \end{array}$

The dependent variable is $\mathrm{DP}_{t}$, the change in the log of the median house price in year $t$ in city $j$, deflated by the national consumer price index. $\mathrm{DI}_{t}$ is the change in the log of the per capita income in year $t$ in city $j$, deflated by the national consumer price index. $P_{t-1} / I_{t-1}$ is the ratio of the median house price to per capita income in year $t$ in city $\mathrm{j}$.

All regressions include city and year dummies.

Robust $\mathrm{t}$-statistics in parenthesis. 


\section{Table 3: Debt Regressions}

\begin{tabular}{|c|c|c|c|c|c|c|}
\hline \multirow[b]{2}{*}{$\mathrm{DI}_{\mathrm{t}}$} & \multicolumn{2}{|c|}{$\begin{array}{l}\text { DEBT = } \\
\text { PACK }\end{array}$} & \multicolumn{2}{|c|}{$\begin{array}{l}\text { DEBT = } \\
\text { YESMTG }\end{array}$} & \multicolumn{2}{|c|}{$\begin{array}{l}\text { DEBT }= \\
\text { MEDIAN }\end{array}$} \\
\hline & $\begin{array}{l}0.077 \\
(0.47)\end{array}$ & $\begin{array}{l}0.088 \\
(0.54)\end{array}$ & $\begin{array}{l}-1.451 \\
(2.13)\end{array}$ & $\begin{array}{l}-1.436 \\
(2.03)\end{array}$ & $\begin{array}{l}-0.373 \\
(1.06)\end{array}$ & $\begin{array}{l}-0.338 \\
(0.95)\end{array}$ \\
\hline $\mathrm{DI}_{t}{ }^{*} \mathrm{DEBT}_{\mathrm{t}-1}$ & $\begin{array}{l}2.268 \\
(2.45)\end{array}$ & $\begin{array}{l}1.784 \\
(1.96)\end{array}$ & $\begin{array}{l}2.687 \\
(2.62)\end{array}$ & $\begin{array}{l}2.666 \\
(2.49)\end{array}$ & $\begin{array}{l}1.460 \\
(2.24)\end{array}$ & $\begin{array}{l}1.332 \\
(2.03)\end{array}$ \\
\hline $\mathrm{DEBT}_{\mathrm{t}-1}$ & & $\begin{array}{l}0.071 \\
(2.31)\end{array}$ & & $\begin{array}{l}0.010 \\
(0.13)\end{array}$ & & $\begin{array}{l}0.039 \\
(1.88)\end{array}$ \\
\hline$D P_{1-1}$ & $\begin{array}{l}0.516 \\
(9.61)\end{array}$ & $\begin{array}{l}0.510 \\
(9.84)\end{array}$ & $\begin{array}{l}0.500 \\
(9.82)\end{array}$ & $\begin{array}{l}0.501 \\
(9.77)\end{array}$ & $\begin{array}{l}0.526 \\
(9.45)\end{array}$ & $\begin{array}{l}0.521 \\
(9.47)\end{array}$ \\
\hline$P_{t-1} / I_{t-1}$ & $\begin{array}{l}-0.192 \\
(7.98)\end{array}$ & $\begin{array}{l}-0.188 \\
(8.04)\end{array}$ & $\begin{array}{l}-0.189 \\
(8.26)\end{array}$ & $\begin{array}{l}-0.189 \\
(8.25)\end{array}$ & $\begin{array}{l}-0.192 \\
(8.02)\end{array}$ & $\begin{array}{l}-0.190 \\
(8.06)\end{array}$ \\
\hline $\begin{array}{l}\text { Implied Avg } \\
\text { Slope on } \\
\mathrm{DI}_{4}\end{array}$ & 0.39 & 0.39 & 0.32 & 0.32 & 0.41 & 0.41 \\
\hline Number of Obs & 370 & 370 & 374 & 374 & 370 & 370 \\
\hline Adjusted R2 & 0.74 & 0.74 & 0.75 & 0.75 & 0.74 & 0.74 \\
\hline
\end{tabular}

The dependent variable is $\mathrm{DP}_{\mathfrak{t}}$, the change in the $\log$ of the median house price in year $t$ in city $\mathrm{j}$, deflated by the national consumer price index. $\mathrm{DI}_{t}$ is the change in the log of the per capita income in year $t$ in city $j$, deflated by the national consumer price index. $P_{t-1} / I_{t-1}$ is the ratio of the median house price to per capita income in year $\mathrm{t}-1$ in city $\mathrm{j}$.

All regressions include city and year dummies

Robust $\mathrm{t}$-statistics in parentheses. 


\section{Table 4: Debt: High vs. Low}

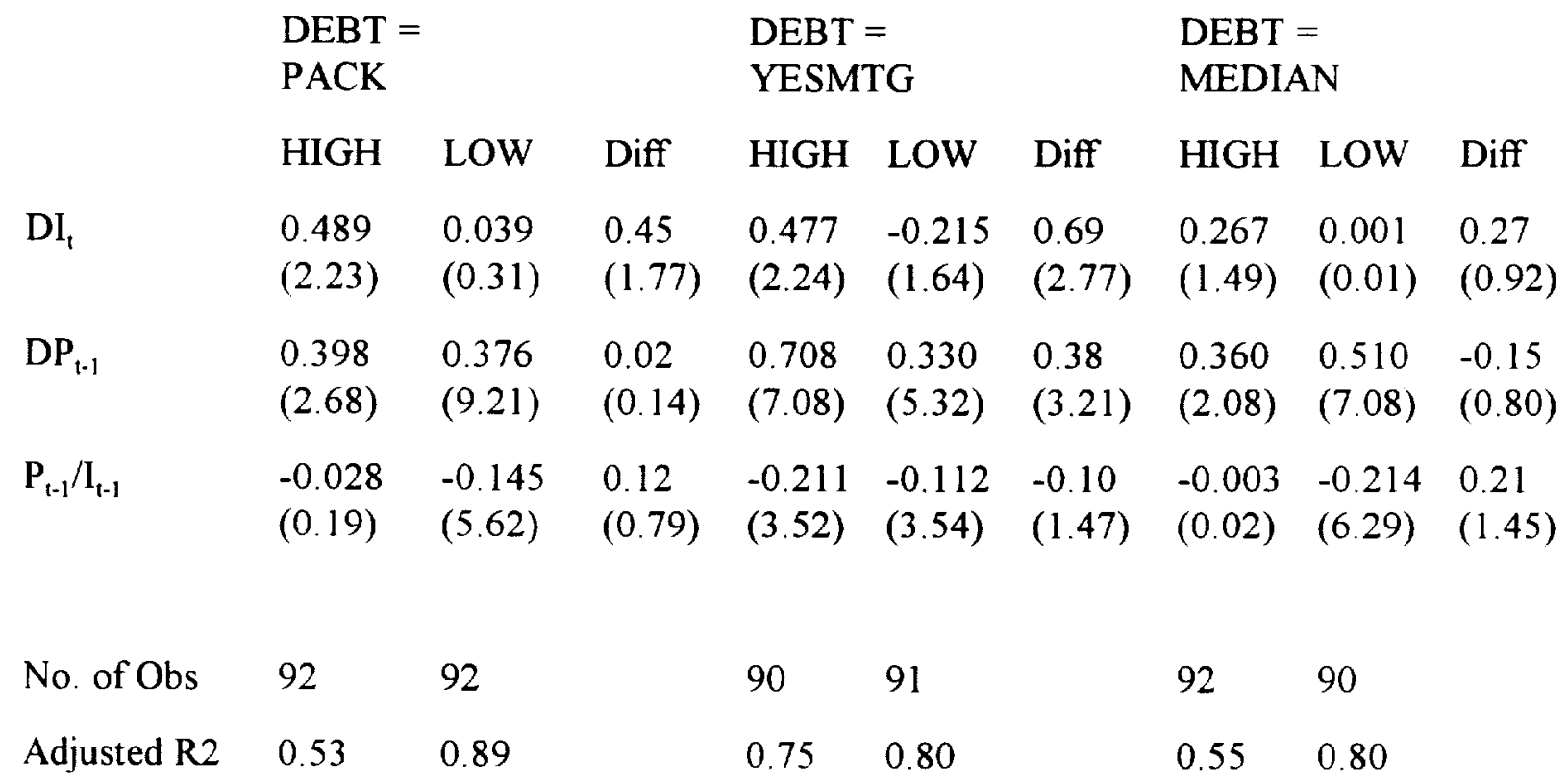

The data are sorted on the debt variable, and split into quartiles. The top and bottom quartiles are used.

The dependent variable is $\mathrm{DP}_{\mathrm{t}}$, the change in the log of the median house price in year $t$ in city $\mathrm{j}$,

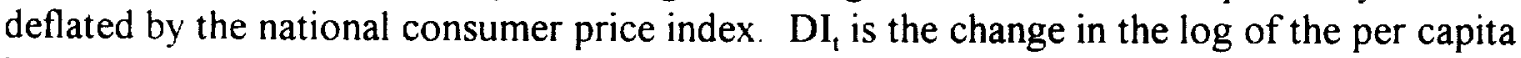
income in year $t$ in city $j$, deflated by the national consumer price index. $P_{t-1} / I_{t-1}$ is the ratio of the median house price to per capita income in year $\mathrm{t}-1$ in city $\mathrm{j}$.

All regressions include city and year dummies.

Robust t-statistics in parentheses 
Table 5: No Outliers

\begin{tabular}{|c|c|c|c|c|c|c|}
\hline \multirow[b]{2}{*}{$\mathrm{DI}_{\mathrm{t}}$} & \multicolumn{2}{|c|}{$\begin{array}{l}\text { DEBT = } \\
\text { PACK }\end{array}$} & \multicolumn{2}{|c|}{$\begin{array}{l}\text { DEBT = } \\
\text { YESMTG }\end{array}$} & \multicolumn{2}{|c|}{$\begin{array}{l}\text { DEBT = } \\
\text { MEDIAN }\end{array}$} \\
\hline & $\begin{array}{l}-0.237 \\
(1.64)\end{array}$ & $\begin{array}{l}-0.236 \\
(1.64)\end{array}$ & $\begin{array}{c}-1.008 \\
(1.92)\end{array}$ & $\begin{array}{l}-0.980 \\
(1.77)\end{array}$ & $\begin{array}{l}-0.819 \\
(2.74)\end{array}$ & $\begin{array}{l}-0.793 \\
(2.64)\end{array}$ \\
\hline $\mathrm{DI}_{\mathrm{t}}{ }^{*} \mathrm{DEBT}_{\mathrm{t}-1}$ & $\begin{array}{l}3.054 \\
(3.47)\end{array}$ & $\begin{array}{l}2.714 \\
(3.11)\end{array}$ & $\begin{array}{l}1.757 \\
(2.21)\end{array}$ & $\begin{array}{l}1.716 \\
(2.05)\end{array}$ & $\begin{array}{l}1.963 \\
(3.61)\end{array}$ & $\begin{array}{l}1.857 \\
(3.39)\end{array}$ \\
\hline DEBT $_{1-1}$ & & $\begin{array}{l}0.051 \\
(1.86)\end{array}$ & & $\begin{array}{l}0.017 \\
(0.23)\end{array}$ & & $\begin{array}{l}0.028 \\
(1.48)\end{array}$ \\
\hline$D P_{t-1}$ & $\begin{array}{l}0.459 \\
(8.81)\end{array}$ & $\begin{array}{l}0.456 \\
(8.97)\end{array}$ & $\begin{array}{l}0.444 \\
(8.81)\end{array}$ & $\begin{array}{l}0.445 \\
(8.83)\end{array}$ & $\begin{array}{l}0.466 \\
(8.83)\end{array}$ & $\begin{array}{l}0.463 \\
(8.85)\end{array}$ \\
\hline$P_{t-1} / I_{t-1}$ & $\begin{array}{l}-0.160 \\
(8.18)\end{array}$ & $\begin{array}{l}-0.158 \\
(8.24)\end{array}$ & $\begin{array}{l}-0.161 \\
(8.42)\end{array}$ & $\begin{array}{l}-0.161 \\
(8.44)\end{array}$ & $\begin{array}{l}-0.159 \\
(8.10)\end{array}$ & $\begin{array}{l}-0.158 \\
(8.16)\end{array}$ \\
\hline Number of Obs & 354 & 354 & 358 & 358 & 354 & 354 \\
\hline Adjusted R2 & 0.75 & 0.75 & 0.75 & 0.75 & 0.75 & 0.75 \\
\hline
\end{tabular}

The top and bottom $1 \%$ of observations sorted on $\mathrm{DP}_{1}$ and $\mathrm{DI}_{1}$ have been dropped.

The dependent variable is $\mathrm{DP}_{\mathrm{t}}$, the change in the log of the median house price in year $t$ in city $\mathrm{j}$, deflated by the national consumer price index. $\mathrm{DI}_{t}$ is the change in the log of the per capita income in year $t$ in city $j$, deflated by the national consumer price index. $P_{t-1} / I_{t-1}$ is the ratio of the median house price to per capita income in year $t-1$ in city $j$.

All regressions include city and year dummies.

Robust $\mathrm{t}$-statistics in parentheses. 


\section{Table 6: First Stage Regressions}

\begin{tabular}{|c|c|c|c|c|c|c|}
\hline & \multicolumn{2}{|l|}{$\begin{array}{l}\text { DEBT = } \\
\text { PACK }\end{array}$} & \multicolumn{2}{|c|}{$\begin{array}{l}\text { DEBT = } \\
\text { YESMTG }\end{array}$} & \multicolumn{2}{|c|}{$\begin{array}{l}\text { DEBT = } \\
\text { MEDIAN }\end{array}$} \\
\hline & Coef & T-stat & Coef & T-stat & Coef & T-stat \\
\hline Constant & -0.04 & -0.38 & 0.45 & 3.34 & 0.40 & 4.76 \\
\hline $\mathrm{DP}_{1}$ & -0.09 & -0.52 & -0.25 & -0.87 & -0.17 & -0.90 \\
\hline$D P_{t-1}$ & -0.22 & -1.31 & -0.23 & -0.70 & 0.06 & 0.34 \\
\hline $\mathrm{DI}_{\mathrm{t}}$ & -0.20 & -0.69 & 0.02 & 0.05 & -0.49 & -1.21 \\
\hline $\mathrm{DI}_{t-1}$ & -1.97 & -6.50 & -3.29 & -7.03 & -0.20 & -0.61 \\
\hline DPOP, $_{1}$ & 5.05 & 4.40 & 8.07 & 4.98 & 1.21 & 1.04 \\
\hline $\operatorname{DPOP}_{\mathrm{t}-1}$ & -3.02 & -2.62 & -4.77 & -2.97 & 1.98 & 1.75 \\
\hline$P_{t-1} / l_{t-1}$ & -0.10 & -3.24 & -0.08 & -1.67 & -0.10 & -3.38 \\
\hline Number of Obs & 109 & & 109 & & 110 & \\
\hline Adjusted R2 & 0.46 & & 0.43 & & 0.31 & \\
\hline
\end{tabular}

The dependent variable is the debt measure. $\mathrm{DP}_{\mathrm{t}}$ is the change in the log of the median house price in year $t$ in city $j$, deflated by the national consumer price index. $\mathrm{DI}_{t}$ is the change in the log of the per capita income in year $t$ in city $j$, deflated by the national consumer price index. $P_{t-1} / I_{t-1}$ is the ratio of the median house price to per capita income in year $t-1$ in city $j$. DPOP is the change in the log of the city's population. 


\section{Table 7: Projected DEBT}

\begin{tabular}{|c|c|c|c|c|c|c|}
\hline \multirow[b]{2}{*}{$\mathrm{DI}_{\mathrm{t}}$} & \multicolumn{2}{|c|}{$\begin{array}{l}\text { DEBT = } \\
\text { PACK }\end{array}$} & \multicolumn{2}{|c|}{$\begin{array}{l}\text { DEBT = } \\
\text { YESMTG }\end{array}$} & \multicolumn{2}{|c|}{$\begin{array}{l}\text { DEBT = } \\
\text { MEDIAN }\end{array}$} \\
\hline & $\begin{array}{l}-0.113 \\
(0.50)\end{array}$ & $\begin{array}{l}-0.124 \\
(0.53)\end{array}$ & $\begin{array}{l}-1.600 \\
(1.42)\end{array}$ & $\begin{array}{l}-1.728 \\
(2.02)\end{array}$ & $\begin{array}{l}-0.668 \\
(1.37)\end{array}$ & $\begin{array}{l}-0.652 \\
(1.27)\end{array}$ \\
\hline $\mathrm{DI}_{\mathrm{t}}{ }^{*} \mathrm{DEBT}_{\mathrm{t}-\mathrm{l}}$ & $\begin{array}{l}3.029 \\
(2.30)\end{array}$ & $\begin{array}{l}3.099 \\
(2.23)\end{array}$ & $\begin{array}{l}2.888 \\
(1.72)\end{array}$ & $\begin{array}{l}3.062 \\
(1.80)\end{array}$ & $\begin{array}{l}1.884 \\
(2.14)\end{array}$ & $\begin{array}{l}1.854 \\
(2.01)\end{array}$ \\
\hline $\operatorname{DEBT}_{t-1}$ & & $\begin{array}{l}-0.009 \\
(0.24)\end{array}$ & & $\begin{array}{l}-0.033 \\
(0.55)\end{array}$ & & $\begin{array}{l}0.004 \\
(0.17)\end{array}$ \\
\hline $\mathrm{DP}_{\mathrm{t}-1}$ & $\begin{array}{l}0.517 \\
(9.78)\end{array}$ & $\begin{array}{l}0.514 \\
(9.40)\end{array}$ & $\begin{array}{l}0.499 \\
(9.80)\end{array}$ & $\begin{array}{l}0.498 \\
(9.68)\end{array}$ & $\begin{array}{l}0.521 \\
(9.65)\end{array}$ & $\begin{array}{l}0.523 \\
(9.27)\end{array}$ \\
\hline$P_{t-1} / I_{t-1}$ & $\begin{array}{l}-0.190 \\
(8.09)\end{array}$ & $\begin{array}{l}-0.191 \\
(7.93)\end{array}$ & $\begin{array}{l}-0.191 \\
(8.17)\end{array}$ & $\begin{array}{l}-0.193 \\
(8.18)\end{array}$ & $\begin{array}{l}-0.193 \\
(8.15)\end{array}$ & $\begin{array}{l}-0.193 \\
(8.08)\end{array}$ \\
\hline Number of Obs & 374 & 374 & 374 & 374 & 374 & 374 \\
\hline Adjusted R2 & 0.75 & 0.75 & 0.74 & 0.74 & 0.75 & 0.75 \\
\hline
\end{tabular}

The debt measure is based on linear regressions of debt on income, population, price, and priceto-income variables

The dependent variable is $\mathrm{DP}_{t}$, the change in the log of the median house price in year $t$ in city $\mathrm{j}$, deflated by the national consumer price index. $\mathrm{DI}_{t}$ is the change in the log of the per capita income in year $t$ in city $j$, deflated by the national consumer price index. $P_{t-1} / I_{t-1}$ is the ratio of the median house price to per capita income in year $t-1$ in city $j$.

All regressions include city and year dummies.

Robust t-statistics in parentheses. 


\section{Table 8: City-Specific Income Terms}

\begin{tabular}{|c|c|c|c|c|c|c|}
\hline \multirow[b]{2}{*}{$\mathrm{DI}_{\mathrm{t}}$} & \multicolumn{2}{|c|}{$\begin{array}{l}\text { DEBT }= \\
\text { PACK }\end{array}$} & \multicolumn{2}{|c|}{$\begin{array}{l}\text { DEBT = } \\
\text { YESMTG }\end{array}$} & \multicolumn{2}{|c|}{$\begin{array}{l}\text { DEBT }= \\
\text { MEDIAN }\end{array}$} \\
\hline & $* *$ & $* *$ & $* *$ & $* *$ & $* *$ & $* *$ \\
\hline $\mathrm{DI}_{1} * \mathrm{DEBT}_{\mathrm{t}-1}$ & $\begin{array}{l}3.950 \\
(2.37)\end{array}$ & $\begin{array}{l}2.900 \\
(1.46)\end{array}$ & $\begin{array}{l}1.824 \\
(0.43)\end{array}$ & $\begin{array}{l}2.829 \\
(0.53)\end{array}$ & $\begin{array}{l}3.854 \\
(3.12)\end{array}$ & $\begin{array}{l}3.862 \\
(3.08)\end{array}$ \\
\hline $\operatorname{DEBT}_{t-1}$ & & $\begin{array}{l}0.048 \\
(1.29)\end{array}$ & & $\begin{array}{l}-0.034 \\
(0.35)\end{array}$ & & $\begin{array}{l}-0.000 \\
(0.01)\end{array}$ \\
\hline $\mathrm{DP}_{\mathrm{t}-1}$ & $\begin{array}{l}0.513 \\
(7.67)\end{array}$ & $\begin{array}{l}0.509 \\
(7.87)\end{array}$ & $\begin{array}{l}0.510 \\
(7.89)\end{array}$ & $\begin{array}{l}0.509 \\
(7.80)\end{array}$ & $\begin{array}{l}0.509 \\
(7.79)\end{array}$ & $\begin{array}{l}0.509 \\
(7.81)\end{array}$ \\
\hline$P_{t-1} / I_{t-1}$ & $\begin{array}{l}-0.182 \\
(7.80)\end{array}$ & $\begin{array}{l}-0.177 \\
(7.84)\end{array}$ & $\begin{array}{l}-0.180 \\
(7.78)\end{array}$ & $\begin{array}{l}-0.180 \\
(7.77)\end{array}$ & $\begin{array}{l}-0.183 \\
(7.87)\end{array}$ & $\begin{array}{l}-0.183 \\
(7.87)\end{array}$ \\
\hline $\begin{array}{l}\text { P-value for } \mathrm{H}_{0} \text { : City- } \\
\text { specific } \mathrm{DI}_{1} \text { are zero }\end{array}$ & 0.62 & 0.77 & 0.92 & 0.92 & 0.49 & 0.58 \\
\hline Number of Obs & 370 & 370 & 374 & 374 & 370 & 370 \\
\hline Adjusted R2 & 0.74 & 0.74 & 0.74 & 0.74 & 0.74 & 0.74 \\
\hline
\end{tabular}

** indicates that the coefficient on $\mathrm{Dl}_{1}$ is allowed to vary across the 44 cities.

"P-value for $\mathrm{H}_{0}$ : City-specific $\mathrm{DI}_{1}$ are zero" is the significance level from an F-test, testing the

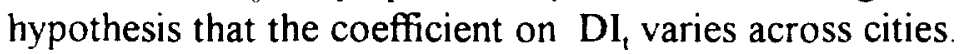

The dependent variable is $\mathrm{DP}_{\mathrm{v}}$, the change in the log of the median house price in year $t$ in city $\mathrm{j}$, deflated by the national consumer price index. $\mathrm{DI}_{t}$ is the change in the log of the per capita income in year $t$ in city $j$, deflated by the national consumer price index. $P_{t-1} / I_{t-1}$ is the ratio of the median house price to per capita income in year $\mathrm{t}-1$ in city $\mathrm{j}$.

All regressions include city and year dummies, and city-specific coefficients on $\mathrm{DI}_{t}$.

Robust t-statistics in parentheses 
Table 9: Population Growth and Debt

\begin{tabular}{|c|c|c|c|c|c|c|}
\hline \multirow[b]{2}{*}{$\mathrm{DI}_{\mathrm{t}}$} & \multicolumn{2}{|c|}{$\begin{array}{l}\text { DEBT = } \\
\text { PACK }\end{array}$} & \multicolumn{2}{|c|}{$\begin{array}{l}\text { DEBT = } \\
\text { YESMTG }\end{array}$} & \multicolumn{2}{|c|}{$\begin{array}{l}\text { DEBT = } \\
\text { MEDIAN }\end{array}$} \\
\hline & $\begin{array}{l}0.072 \\
(0: 2)\end{array}$ & $\begin{array}{l}0.077 \\
(0.45)\end{array}$ & $\begin{array}{l}-1.535 \\
(2.25)\end{array}$ & $\begin{array}{l}-1.537 \\
(2.14)\end{array}$ & $\begin{array}{l}-0.375 \\
(1.06)\end{array}$ & $\begin{array}{l}-0.339 \\
(0.96)\end{array}$ \\
\hline $\mathrm{DI}_{\mathrm{t}}{ }^{*} \mathrm{DEBT}_{\mathrm{t}-1}$ & $\begin{array}{l}2.241 \\
(2.31)\end{array}$ & $\begin{array}{l}1.718 \\
(1.78)\end{array}$ & $\begin{array}{l}2.868 \\
(2.71)\end{array}$ & $\begin{array}{l}2.883 \\
(2.56)\end{array}$ & $\begin{array}{l}1.481 \\
(2.15)\end{array}$ & $\begin{array}{l}1.320 \\
(1.89)\end{array}$ \\
\hline $\operatorname{DEBT}_{t-1}$ & & $\begin{array}{l}0.072 \\
(2.31)\end{array}$ & & $\begin{array}{l}0.004 \\
(0.06)\end{array}$ & & $\begin{array}{l}0.039 \\
(1.86)\end{array}$ \\
\hline $\mathrm{DI}_{t}{ }^{*} \mathrm{DPOP}_{\mathrm{t}-1}$ & $\begin{array}{l}0.565 \\
(0.10)\end{array}$ & $\begin{array}{l}1.313 \\
(0.23)\end{array}$ & $\begin{array}{l}-2.700 \\
(0.50)\end{array}$ & $\begin{array}{l}-3.059 \\
(0.55)\end{array}$ & $\begin{array}{l}-0.622 \\
(0.11)\end{array}$ & $\begin{array}{l}0.388 \\
(0.06)\end{array}$ \\
\hline $\mathrm{DPOP}_{t-1}$ & & $\begin{array}{l}-0.012 \\
(0.06)\end{array}$ & & $\begin{array}{l}0.054 \\
(0.29)\end{array}$ & & $\begin{array}{l}-0.024 \\
(0.13)\end{array}$ \\
\hline $\mathrm{DP}_{1-1}$ & $\begin{array}{l}0.516 \\
(9.62)\end{array}$ & $\begin{array}{l}0.510 \\
(9.96)\end{array}$ & $\begin{array}{l}0.500 \\
(9.82)\end{array}$ & $\begin{array}{l}0.498 \\
(9.84)\end{array}$ & $\begin{array}{l}0.526 \\
(9.47)\end{array}$ & $\begin{array}{l}0.521 \\
(9.60)\end{array}$ \\
\hline$P_{t-1} / I_{t-1}$ & $\begin{array}{l}-0.192 \\
(7.94)\end{array}$ & $\begin{array}{l}-0.188 \\
(8.00)\end{array}$ & $\begin{array}{l}-0.189 \\
(8.16)\end{array}$ & $\begin{array}{l}-0.189 \\
(8.12)\end{array}$ & $\begin{array}{l}-0.192 \\
(7.96)\end{array}$ & $\begin{array}{l}-0.190 \\
(7.99)\end{array}$ \\
\hline Number of Obs & 370 & 370 & 374 & 374 & 370 & 370 \\
\hline Adjusted $\mathrm{F}$ & 0.74 & 0.74 & 0.75 & 0.75 & 0.74 & 0.74 \\
\hline
\end{tabular}

The dependent variable is $\mathrm{DP}_{\mathrm{t}}$, the change in the log of the median house price in year $t$ in city $\mathrm{j}$, deflated by the national consumer price index. $\mathrm{DI}_{1}$ is the change in the log of the per capita income in year $t$ in city $j$, deflated by the national consumer price index. $P_{t-1} / I_{t-1}$ is the ratio of the median house price to per capita income in year $t-1$ in city $j$. DPOP ${ }_{t}$ is the change in the log of the city's population.

All regressions include city and year dummies.

Robust $\mathrm{t}$-statistics in parentheses 
Figure 1:Dynamic Response of Price to Income

Without Estimated Debt Effect, Table 2, Column 6

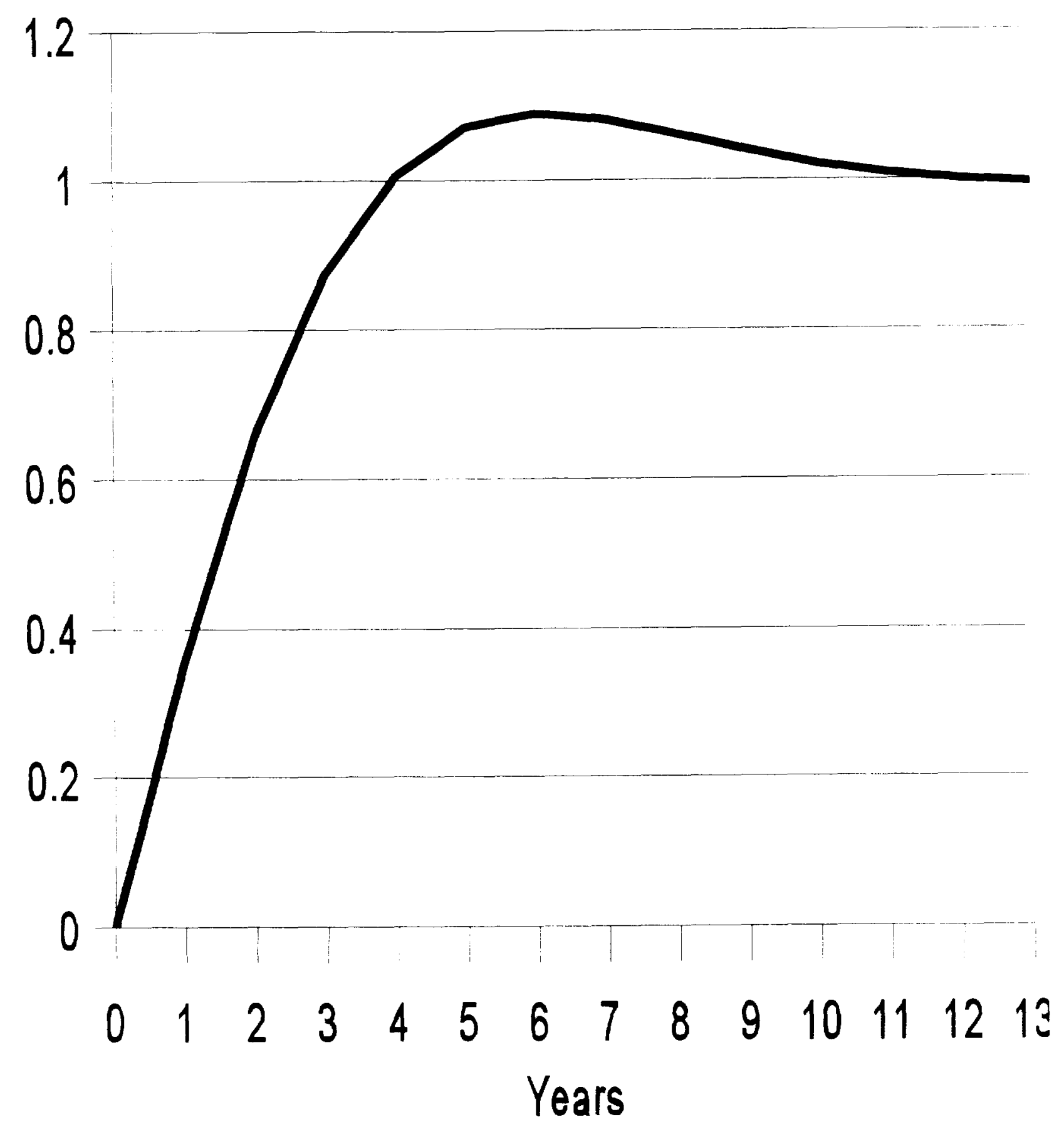


Figure 2:Dynamic Response of Price to Income

Estimated Debt Effect From Table 3, Column 1

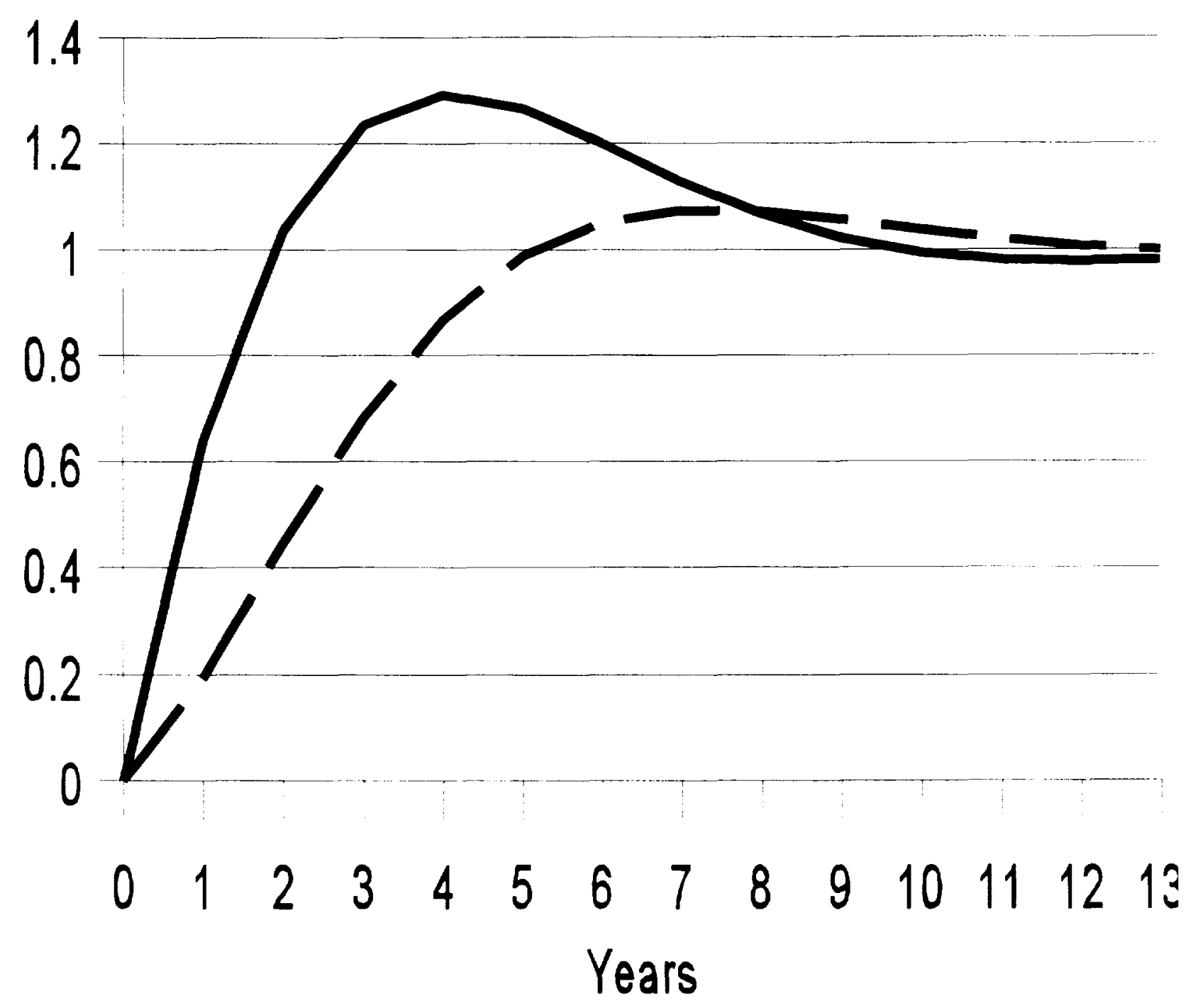

High Debt (90th Percentile)

- - Low Debt (10th Percentile) 
Figure 3: Dynamic Response of Price to Income Estimated Debt Effect From Table 4, Columns 1 and 2

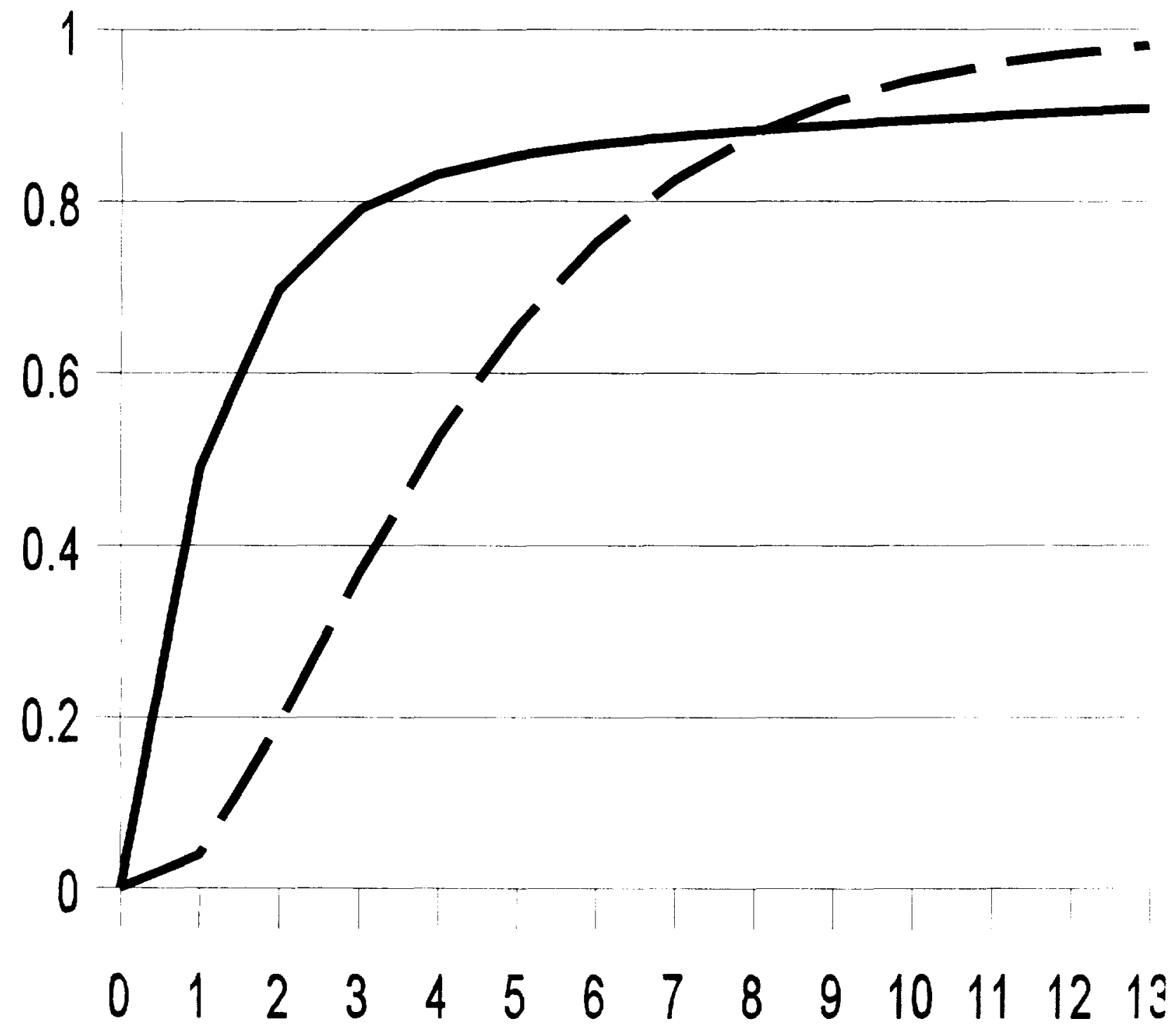

— High Quartile

- - Bottom Quartile 
Figure 4:Dynamic Response of Price to Income

Estimated Debt Effect From Table 7, Column 1

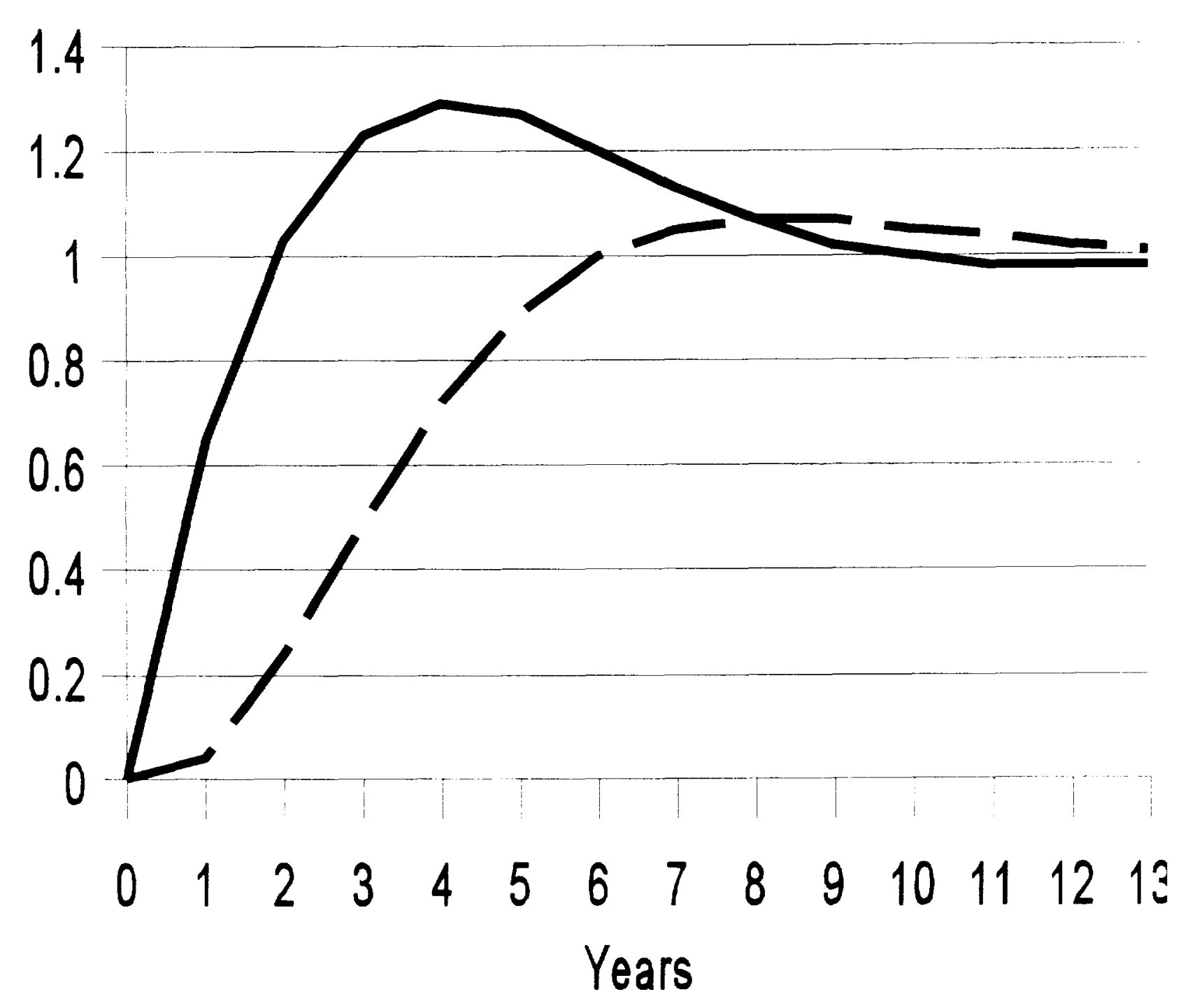

High Debt (90th Percentile)

- Low Debt (10th Percentile) 